\title{
BACILLUS CEREUS FOOD POISONING: A PROVISIONAL SEROTYPING SCHEME
}

\author{
A. J. TAYLOR* AND R. J. GILBERT \\ Food Hygiene Laboratory, Central Public Health Laboratory, \\ Colindale Avenue, London NW9 SHT
}

SINCE the latter part of 1971 , more than 40 incidents of food poisoning associated with the consumption of cooked rice, usually from Chinese restaurants and "take-away" shops, have been reported in this country. All of these episodes have been attributed to Bacillus cereus (Public Health Laboratory Service, 1972, 1973; Mortimer and McCann, 1974; Gilbert and Taylor, 1975a and $b$ ). The illness has been characterised by an acute attack of nausea and vomiting usually occurring between 1 and $5 \mathrm{~h}$ after a meal; diarrhoea was not a common feature.

These episodes and similar ones reported from Australia (Dr J. Taplin, personal communication), Canada (Lefebvre et al., 1973) and the Netherlands (Dr M. D. Northolt, personal communication) exhibit features that differ from those of other outbreaks attributed to B. cereus and reported in several countries, particularly in Northern and Eastern Europe (Hauge, 1950, 1955; Goepfert, Spira and Kim, 1972). In the latter countries a wide variety of foods including meat and vegetable soups, cooked meat and poultry, cooked vegetables, and puddings and sauces have been implicated, and the illness was characterised by symptoms of diarrhoea and abdominal pain between 8 and $16 \mathrm{~h}$ after ingestion of food; vomiting was rare.

In view of the apparent existence of two distinct types of illness caused by the same organism, and the frequently reported occurrence of $B$. cereus in a wide variety of foods (Nygren, 1962), a search has been undertaken for characteristics that could be used to differentiate strains of this organism and that might prove useful for typing. Gilbert and Taylor (1975b) reported that fermentation of salicin was a useful test for the separation of strains of $B$. cereus involved in outbreaks of food poisoning associated with rice from those isolated from the environment and foods not connected with food-poisoning incidents.

Norris and Wolf (1961) studied the antigens of a number of aerobic sporing bacilli including $B$. cereus and demonstrated that, whilst the spore antigen possessed the highest species specificity, the flagellar $(\mathrm{H})$ antigen provided the highest degree of strain specificity. $\mathrm{H}$ agglutinogens provide the basis of the successful serological classification of the insect pathogen $B$. thuringiensis. de Barjac and Bonnefoi (1962) and Bonnefoi and de Barjac (1963) recognised eight groups of $B$. thuringiensis. Norris (1964) added a ninth serogroup and

Received 24 Dec. 1974; accepted 22 Apr. 1975.

*Present address: Diagnostic Bacteriology Laboratory, St Mary's Hospital Medical School (University of London), Paddington, London W2.

J. MED. MICROBIOL.-VOL. 8 (1975) 
showed a relationship between the serogroups and groups obtained by biochemical differentiation and electrophoretic analyses. One previous study of the $\mathrm{H}$ antigens of $\boldsymbol{B}$. cereus was made by Lemille, de Barjac and Bonnefoi (1969) who demonstrated 17 serotypes among 33 cultures, mainly isolates from insects.

The present paper describes the application of a provisional typing scheme to the epidemiology of $B$. cereus food poisoning.

\section{MATERIALS AND METHODS}

Strains. The strains of $B$. cereus used for the production of antisera are listed with their sources in table I. Four strains (nos. 4429, 4431, 4432 and 4433) were supplied by Dr J. M. Goepfert, Food Research Institute, University of Wisconsin, Madison, Wisconsin, USA, and strain no. CAN30 by Dr E. Todd, Microbiology Division, Food Research Laboratories, Health and Welfare Canada, Ottawa, Canada.

A further 124 isolates from 32 British outbreaks of food poisoning attributed to $B$. cereus were received from Public Health Laboratory Service and hospital laboratories in Great Britain. Three isolates from two similar episodes in Australia were sent by Dr Jennifer Taplin, Microbiology Diagnostic Unit, University of Melbourne, Victoria, Australia.

Ten strains of $B$. thuringiensis, each representative of a different serotype, were supplied by Professor J. R. Norris, Meat Research Insitute, Langford, Bristol.

Isolation of $B$. cereus from uncooked rice. Sixty-three samples of uncooked long-grain rice were obtained from Chinese and Indian restaurants in the North London area and portions, c. $25 \mathrm{~g}$, were incubated in nutrient broth for $18 \mathrm{~h}$ at $35^{\circ} \mathrm{C}$. Subcultures were made on to blood agar. The identity of $B$. cereus colonies was confirmed by further studies, including subculture on Kendall's B.C. medium and fermentation tests with glucose, arabinose mannitol and xylose (Gilbert and Taylor, 1975b).

\section{Serology}

Preparation of flagellar " $H$ " antigen. Cultures were grown in Craigie tubes containing semi-solid nutrient agar incubated at $30^{\circ} \mathrm{C}$ for $18-48 \mathrm{~h}$. Several passages through fresh tubes were made to ensure active motility. Ninety-ml volumes of nutrient broth in $250-\mathrm{ml}$ conical flasks were seeded with the surface growth from the final Craigie tube and incubated at $35^{\circ} \mathrm{C}$ on a rotary shaker $\left(100\right.$ r.p.m.). After incubation for $5 \mathrm{~h}$ at $35^{\circ} \mathrm{C}$ the suspensions were examined by phase-contrast microscopy for active motility and the absence of spores. Formalin was added to a final concentration of $1 \%(\mathrm{v} / \mathrm{v})$ and the suspensions were stored at $4^{\circ} \mathrm{C}$.

Somatic " $O$ " antigen. Cultures were grown on nutrient agar at $35^{\circ} \mathrm{C}$ for $48 \mathrm{~h}$. Ninety$\mathrm{ml}$ volumes of nutrient broth were seeded from these cultures and incubated on a rotary shaker at $35^{\circ} \mathrm{C}$ for $5 \mathrm{~h}$. The suspensions were held at $100^{\circ} \mathrm{C}$ for $1 \mathrm{~h}$ and stored at $4^{\circ} \mathrm{C}$.

Preparation of antiserum. Antigen suspensions were washed five times in physiological saline and the final deposit resuspended to give a turbidity equivalent to that of a Wellcome Opacity Tube no. 6.

$\mathbf{H}$ antisera were prepared in rabbits by the intravenous administration of five doses of antigen; $0 \cdot 2-, 0 \cdot 5-, 1 \cdot 0-, 2 \cdot 0-$ and $2 \cdot 0-\mathrm{ml}$ volumes were given at 3-day intervals. The preparation of $\mathrm{O}$ antisera followed the same programme but with the addition of a further three injections of $2 \mathrm{ml}$ of antigen at 3-day intervals. The rabbits were rested for 7 days after the final dose and bled by cardiac puncture. The sera were stored at $-30^{\circ} \mathrm{C}$.

Agglutination tests. Tests were carried out in WHO agglutination trays. Doubling dilutions of $0 \cdot 25-\mathrm{ml}$ portions of serum were made and equal volumes of antigen suspension added. Trays were incubated at either $50^{\circ} \mathrm{C}$ for $2 \mathrm{~h}$ for $\mathrm{H}$ antisera or $35^{\circ} \mathrm{C}$ for $18 \mathrm{~h}$ for $\mathrm{O}$ antisera.

Absorption tests (H antisera only). Five-ml volumes of nutrient broth were seeded with 
an actively motile culture of $B$. cereus and incubated for $4 \mathrm{~h}$ at $30^{\circ} \mathrm{C}$. Two plates (6-in. diameter) of nutrient agar were flooded with the culture, excess broth removed and the plates incubated at $30^{\circ} \mathrm{C}$ for $18 \mathrm{~h}$. The growth from these plates was scraped off the agar and mixed with $2 \mathrm{ml}$ of a 1 in 10 dilution of serum in a centrifuge tube. The suspension was incubated at $50^{\circ} \mathrm{C}$ for $2 \mathrm{~h}$, centrifuged and the supernate removed for agglutination tests.

\section{RESULTS}

The 18 strains of $B$. cereus listed in table I were used to prepare agglutinating sera against the $\mathrm{H}$ antigen. The 18 strains included representatives of outbreaks in Great Britain over a period of 3 years, and of incidents in Canada, the Netherlands and the USA, as well as strains isolated from routine samples of foodstuffs, and one clinical isolate. Each of the sera agglutinated its homologous cell suspension to a titre within the range 1280-20 480. Table II shows the cross-agglutination reactions of these antisera and the antigens against which they were prepared.

Cross-absorption tests were performed on the 18 sera and no significant absorption occurred with any $B$. cereus antigen-antiserum combination. When the $B$. cereus antisera were absorbed with known serotypes of $B$. thuringiensis, it was found that the agglutinating antibodies of serum no. 18 were completely absorbed by suspensions of $B$. thuringiensis serotypes IVA and IVB. No other cross-reactions were observed.

$\mathrm{H}$-agglutination tests were done with the 18 antisera and a total of 137 isolates of B. cereus from 34 British and Australian outbreaks of food poisoning associated with cooked rice were serotyped (table III). Table IV shows the distribution of serotypes in these outbreaks. Most of the isolates were of

TABLE I

Details of selected strains of Bacillus cereus used for the preparation of antisera

\begin{tabular}{|c|c|c|c|}
\hline $\begin{array}{c}\text { Strain } \\
\text { no. }\end{array}$ & Source & Country & $\begin{array}{c}\text { Antiserum } \\
\text { no. }\end{array}$ \\
\hline $\begin{array}{r}88 \\
4433 \\
214 \\
264 \\
186 \\
\text { CAN30 } \\
277 \\
4431 \\
4429 \\
4432 \\
2140 \\
118 \\
167 \\
262 \\
\text { RR60 } \\
\text { RR } 43 \\
202 \\
6833\end{array}$ & $\begin{array}{l}\text { Vomitus } \\
\text { Meat loaf } \\
\text { Boiled rice } \\
\text { Fried rice } \\
\text { Fried rice } \\
\text { Barbecued chicken } \\
\text { Curry powder } \\
\text { Indonesian rice dish } \\
\text { Vanilla pudding } \\
\text { Indonesian rice dish } \\
\text { Neonatal brain abscess } \\
\text { Risotto } \\
\text { Prawn curry and rice } \\
\text { Fried rice } \\
\text { Uncooked rice } \\
\text { Uncooked rice } \\
\text { Uncooked rice } \\
\text { Uncooked rice }\end{array}$ & $\begin{array}{l}\text { Great Britian } \\
\text { USA } \\
\text { Great Britain } \\
\text { Canada } \\
\text { Great Britain } \\
\text { Netherlands }\end{array}$ & $\begin{array}{r}1 \\
2 \\
3 \\
4 \\
5 \\
6 \\
7 \\
8 \\
9 \\
10 \\
11 \\
12 \\
13 \\
14 \\
15 \\
16 \\
17 \\
18\end{array}$ \\
\hline
\end{tabular}




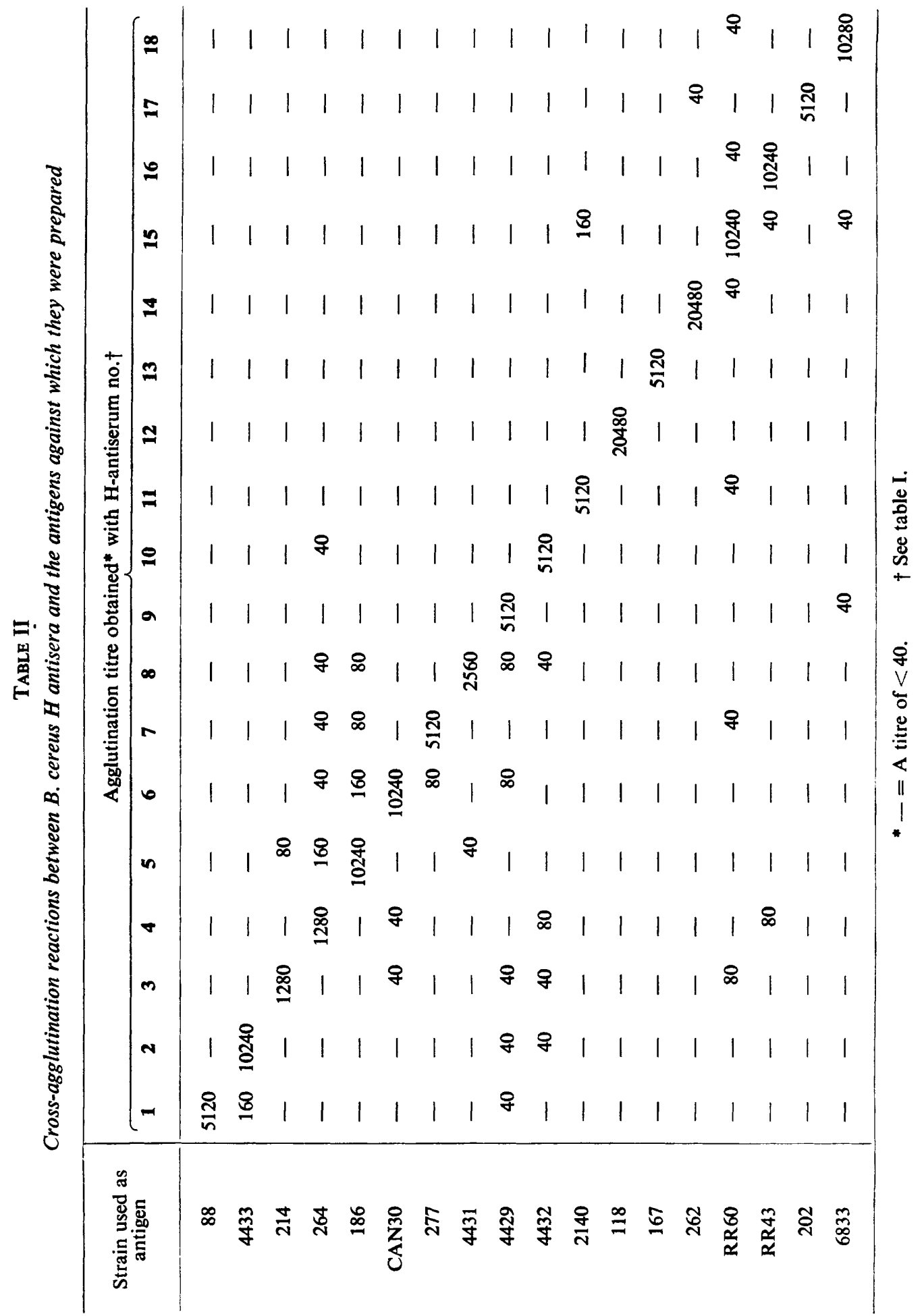


type 1: 56 of $84(66 \cdot 7 \%)$ from samples of food, and 43 of $53(81 \cdot 1 \%)$ from clinical specimens. In 19 of the 34 outbreaks, food, clinical specimens or both yielded $B$. cereus of type 1 only. Type 1 strains were isolated from foods, clinical specimens or both in seven other outbreaks but together with other serotypes. B. cereus of type 5 appeared to be solely responsible for four outbreaks, and type 3 for one outbreak. In one episode, serotypes 8 and 13 were isolated. Untypable strains were isolated from two outbreaks.

A total of 66 isolates of B. cereus were cultured from 56 of 63 samples of uncooked rice obtained from various restaurants; the serotypes encountered among the 66 isolates are shown in table V. The majority (38 of $66 ; 57.6 \%$ ) of the isolates were untypable with the 18 sera. Seventeen $(25.8 \%)$ of the isolates were of types $12,15,17$ or 18 , whereas only five were of types 1,3 or 5 .

Several samples of uncooked rice yielded multiple serotypes; for example, one sample contained types 3 and 12 and an untypable strain.

Attempts to produce agglutinating sera against the $O$ antigen were less successful than against the $\mathrm{H}$ antigen. Titres obtained with the $\mathrm{O}$ preparations were within the low range of $80-160$ and there were many cross-reactions at titres of $40-80$.

\section{Discussion}

Of the $18 \mathrm{H}$ serotypes of $B$. cereus described in this study, three (types 1,3 and 5) were most commonly associated with the outbreaks of food poisoning that we investigated. One of the three serotypes was involved, either alone or in combination with others, in 31 of the 34 outbreaks; all 34 were associated

\section{TABLE III}

Occurrence of serotypes among 137 isolates of B. cereus from 34 British and Australian outbreaks of food poisoning associated with cooked rice

\begin{tabular}{|c|c|c|}
\hline $\begin{array}{l}\text { Source of } \\
\text { isolate }\end{array}$ & Serotype & $\begin{array}{l}\text { Number of } \\
\text { isolates }\end{array}$ \\
\hline $\begin{array}{l}\text { Food samples } \\
\text { (84 isolates) }\end{array}$ & $\begin{array}{c}1 \\
5 \\
8 \\
12 \\
13 \\
3 \\
14 \\
18 \\
\text { NT }^{*} \\
4 \\
7 \\
17\end{array}$ & $\begin{array}{l}56(66 \cdot 7 \%) \\
8 \\
3 \\
3 \\
3 \\
2 \\
2 \\
2 \\
2 \\
1 \\
1 \\
1\end{array}$ \\
\hline $\begin{array}{l}\text { Clinical specimens } \\
\text { (53 isolates) }\end{array}$ & $\begin{array}{r}1 \\
5 \\
3 \\
8 \\
\text { NT }\end{array}$ & $\begin{array}{c}43(81 \cdot 1 \%) \\
3 \\
2 \\
2 \\
3\end{array}$ \\
\hline
\end{tabular}

* NT = untypable. 
TABLE IV

Distribution of serotypes of $B$. cereus from 34 outbreaks of food poisoning associated with cooked rice

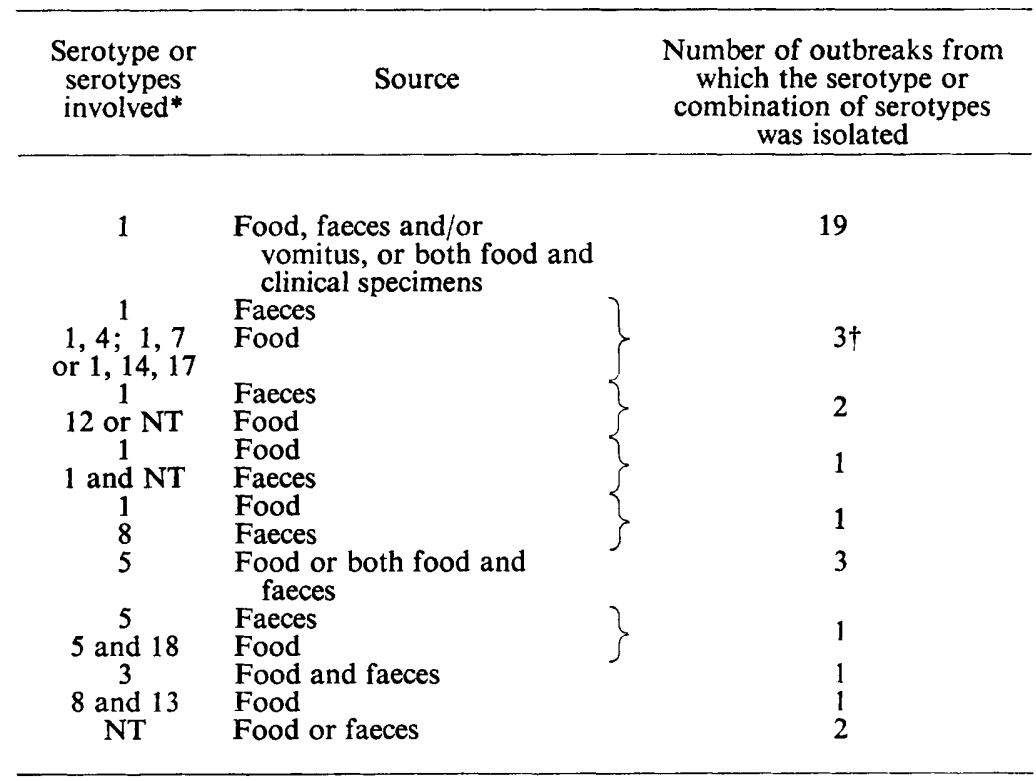

* NT $=$ untypable.

$\dagger$ The distribution in these 3 outbreaks was: (i) type 1 from faeces, types 1 and 4 from food: (ii) type 1 from faeces, types 1 and 7 from food; (iii) type 1 from faeces, types 1,14 and 17 from food.

\section{TABLE V}

Distribution of serotypes among 66 isolates of B. cereus from 56 of 63 samples of uncooked rice*

\begin{tabular}{c|c}
\hline Serotype & $\begin{array}{c}\text { Number of isolates } \\
\text { (and percentage occurrence) }\end{array}$ \\
\hline Untypable & $38(57 \cdot 6)$ \\
17 & $5(7 \cdot 5)$ \\
12 & $4(6 \cdot 1)$ \\
15 & $4(6 \cdot 1)$ \\
18 & $4(6 \cdot 1)$ \\
1 & $3(4 \cdot 5)$ \\
13 & $2(3 \cdot 0)$ \\
3 & $1(1 \cdot 5)$ \\
5 & $1(1 \cdot 5)$ \\
8 & $1(1 \cdot 5)$ \\
11 & $1(1 \cdot 5)$ \\
14 & $1(1 \cdot 5)$ \\
16 & $1(1 \cdot 5)$ \\
\hline
\end{tabular}

* B. cereus was not isolated from seven of the samples. 
with the consumption of cooked rice. Type 1 was the most common serotype isolated and appeared to be responsible for more than half of the outbreaks.

These observations raise a number of questions. Are only certain serotypes of $B$. cereus capable of producing the emetic toxin responsible for the outbreaks, or are there factors such as heat resistance or growth rate that are selective for certain serotypes during the cooking and storage of rice? There seems little doubt that the uncooked rice is the source of $B$. cereus because the organism was isolated from 56 of $63(89 \%)$ samples of uncooked rice. Gilbert, Stringer and Peace (1974) found that the storage of boiled or fried rice at kitchen temperature provides excellent conditions for the germination and outgrowth of $B$. cereus spores that have survived the boiling and frying process.

The findings of Gilbert, Stringer and Peace (1974) in studies with a small number of strains may help to explain the difference between the frequency of serotypes isolated from uncooked rice and from cooked foods incriminated in food-poisoning incidents. There was no significant difference between the growth rates of type- 1 isolates of $B$. cereus from outbreaks and a type-18 isolate from a sample of uncooked rice, but the type-1 isolates were more heat resistant both in aqueous suspension and in rice during cooking. This merits further study with more strains.

The results of serotyping support the theory that $B$. cereus may cause two distinct forms of food-borne illness. The strains available from incidents of food poisoning in the USA, Canada and continental Europe that are characterised by a longer incubation period and that have diarrhoea as the main symptom have provided serotypes of $2,6,8,9$ and 10 , whereas those causing the rice-associated emetic illness in Great Britain and Australia are usually of serotypes 1,3 or 5 . These serological differences are paralleled by differences in salicin fermentation (Gilbert and Taylor, 1975b). Work is in progress on the isolation and purification of the toxins associated with $B$. cereus food poisoning and it is hoped that this work together with feeding tests will elucidate the apparent differences in incubation time and clinical symptoms observed in outbreaks in different countries.

\section{SUMMARY}

A provisional serotyping scheme for Bacillus cereus has been developed. Eighteen selected cultures of $B$. cereus isolated from foods and clinical specimens were used to prepare agglutinating sera against the flagellar antigen. There were no significant cross-reactions between the sera.

The sera were used to type 137 isolates of $B$. cereus from 34 British and Australian incidents of food poisoning associated with the consumption of cooked rice. The majority of the isolates from samples of food ( 56 of $84 ; 66.7 \%$ ) and from clinical specimens ( 43 of $53 ; 81.1 \%$ ) were of H-serotype 1 . Types 1 , 3 and 5 were isolated from foods, clinical specimens or both, obtained from 31 of the 34 episodes.

Sixty-six isolates of $B$. cereus were obtained from 63 samples of uncooked long-grain rice. The majority of the isolates ( 38 of $66 ; 57.6 \%)$ were untypable and types 1,3 and 5 made up only 5 of $66(7.5 \%)$ of the total. 
The results support the theory that $B$. cereus may cause two distinct forms of foodborne illness. Strains from incidents of food poisoning characterised by a longer incubation period and with diarrhoea as the main symptom have provided serotypes $2,6,8,9$ and 10 , whereas those causing the rice-associated emetic illness are usually serotypes 1,3 or 5 .

We are grateful to the many Directors of Public Health Laboratories and Hospital Consultant Bacteriologists for sending us cultures and epidemiological data and to the Chief Environmental Health Officers of the London boroughs of Barnet, Haringey and Hillingdon for supplying the samples of uncooked rice.

\section{REFERENCES}

BarJaC, H. DE AND Bonnefor, A. 1962. Essai de classification biochimique et sérologique de 24 souches de Bacillus du type thuringiensis. Entomophaga, 7, 5.

Bonnefol, A. AND DE BARJAC, H. 1963. Classification des souches du groupe Bacillus thuringiensis par la determination de l'antigène flagellaire. Entomophaga, 8, 223.

Gilbert, R. J., Stringer, M. F. AND PEAce, T. C. 1974. The survival and growth of Bacillus cereus in boiled and fried rice in relation to outbreaks of food poisoning. J. Hyg., Camb., 73, 433.

Gilbert, R. J. AND TAYLOR, A. J. 1975a. Das Auftreten von Bacillus cereus-Lebensmittelvergiftungen in Grossbrittannien. Arch. Lebensmittelhyg., 26, 38.

Gilbert, R. J. AND TAYLOR, A. J. 1975b. Bacillus cereus food poisoning. In Microbiological trends in agriculture, fisheries and food (Soc. Appl. Bact. Symp. Series No. 4), London and New York, in the press.

GoEpfert, J. M., SPIRA, W. M. AND KIM, H. U. 1972. Bacillus cereus: food poisoning organism. A review. J. Milk Fd. Technol., 35, 213.

HaUge, S. 1950. Matforgiftninger fremkalt av Bacillus cereus. Foreløpig meddelelse. Nord. hyg. Tidskr., 31, 189.

Hauge, S. 1955. Food poisoning caused by aerobic spore-forming bacilli. J. appl. Bact., $18,591$.

Lefebvre, A., Gregoire, C. A., Brabant, W. AND Todd, E. 1973. Suspected Bacillus cereus food poisoning. Epidem. bull., Ottawa, 17, 108.

Lemille, F., De BARJAC, H. AND BonNeFoI, A. 1969. Étude sérologique de Bacillus cereus. Mise en évidence de divers sérotypes basés sur les antigènes flagellaires. Annls Inst. Pasteur, Paris, 117, 31.

Mortimer, P. R. AND MCCANN, G. 1974. Food poisoning episodes associated with Bacillus cereus in fried rice. Lancet, $1,1043$.

NoRrIs, J. R. 1964. The classification of Bacillus thuringiensis. J. appl. Bact., 27, 439.

NoRrIs, J. R. AND WOLF, J. 1961. A study of antigens of the aerobic spore-forming bacteria. J. appl. Bact., 24, 42.

Nygren, B. 1962. Phospholipase C-producing bacteria and food poisoning. Acta path. microbiol. scand. Suppl., 160, 1.

Public Health Laboratory Service. 1972. Food poisoning associated with Bacillus cereus. Br. med. J., 1, 189.

Public Health Laboratory Service. 1973. Bacillus cereus food poisoning. Br. med. J., 3, 647 . 